\section{Cooperation Between Vocational Schools and Business in Poland: Schools' vs. Employers' Perspective}

\author{
Piotr Maleszyk \\ Faculty of Economics \\ Maria Curie-Sktodorwska University in Lublin, Poland \\ piotr.maleszyk@poczta.umcs.lublin.pl
}

\author{
Cooperation \\ Between \\ Vocational \\ Schools \\ and Business \\ in Poland: \\ Schools' \\ vs. Employers' \\ Perspective
}

\begin{abstract}
Purpose - The aim of the article is to identify the barriers to cooperation between vocational schools and employers.

Design/Methodology/Approach - The main data source are the results of two surveys (CAWI): on vocational schools in Lublin, and on employers cooperating with those schools.

Findings - The results show the asymmetry of schools' and enterprises' objectives, which should be regarded as an important barrier to the development of cooperation between the two. Employers are set on increasing the number of hours of students' practical vocational training in the workplace, but are reluctant to undertake more costly and more demanding forms of cooperation with schools, like participating in vocational exams, training teachers or providing equipment for school workshops. Meanwhile, schools primarily indicate the need to improve their own resources, especially workshop equipment. They often consider the present state of cooperation with business as satisfactory. Employers' limited willingness to cooperate stems i.a. from fragmentation of the enterprise sector in Poland, poorly developed cooperative bonds between enterprises, and the small scale of recruitment problems during most of the last two decades.

Practical implications - The results allow for the identification of these forms of cooperation between schools and employers, which should be supported by EU structural funds.

Value - The research is based on information of high substantive value from the employers who already have experience in cooperation with vocational schools. Results contribute to the formulation of the view on the effects of the reform of vocational education in Poland.
\end{abstract}

Keywords - vocational education and training, vocational education and enterprises, VET and the labour market, VET in Poland

\section{Introduction}

Strengthening the cooperation of vocational schools with employers by introducing dual education system is one of the most frequently articulated demands in the discussions on the modernisation of vocational education in Poland (Kabaj, 2010; Jeruszka, 2012; NCFSVCE, 2011). German dual system is often indicated as a model example of such collaboration. The system plays an important role in ensuring high competitiveness of German industry (Thelen, 2007; Deissinger, Hellwig, 2005). Dual education is based on practical vocational training and on acquisition of social competences in a workplace, with

\section{Psynergia}

International Journal of Synergy and Research Vol. 6, 2017 pp. 91-104 
IJSR

6 the role of schools reduced to the provision of good theoretical background (DziedziczakFoltyn, Brzeziński, 2013). As indicated by the analyses of the OECD, high degree of employers' commitment, which includes financial help, as well as of the commitment of other social partners to the process of education is the greatest asset of the German dual education system. Employers' involvement allows for the adjustment of education system to the demand on the labor market (Hoeckel, 2008). Elements of dual education were introduced by the reform of Polish vocational education implemented since 2012'.

The implementation of dual education in Poland encounters numerous barriers. The most common arguments indicate poor organisation of vocational education. Less frequent are the remarks concerning factors connected with the economic and social environment of schools. Even less attention is paid to the asymmetry of goals and expectations of schools and enterprises, which reduces the incentives to cooperate. Against this background the aim of the article is to identify the barriers to cooperation between vocational schools and employers. In particular, the article will analyse the differences in the interests of schools and employers. Subsequently, structural features of the business sector and the situation on the labor market will be studied. Achievement of the research purpose will indirectly contribute to the formulation of the view on the effects of the reform of vocational education in Poland. It will also allow for the identification of these forms of cooperation between schools and employers which should be supported by EU structural funds.

\section{Data sources and research methodology}

The article uses different data sources and research methods. The research has covered vocational schools located in the City of Lublin and employers collaborating with those schools. A survey carried out in February 2016 by means of the Computer-Assisted Web Interview (CAWI) method is the main source of information on employers' preferences. The link to an anonymous questionnaire consisting of 14 questions (mainly closed ones) was sent through vocational schools in Lublin to employers, who provided vocational training in the school year 2014/2015. As a result, 95 complete questionnaires were obtained $^{2}$. Such scope of research allowed for obtaining information of high substantive value from the employers who already have knowledge about the functioning of vocational schools and have experience in cooperation with them. This is a significant advantage over the majority of surveys on vocational education conducted in Poland among entrepreneurs (e.g. IBRKK, 2010; NCFSVCE, 2011; Kicia, Zajkowski, 2012), which used samples representing enterprises in general, thus predominantly the firms with no experience in cooperation with vocational schools.

The main data source on the opinions of schools' representatives consists of a survey carried out by means of the CAWI method in vocational schools in the City of Lublin between December 2015 and March 2016. The standardised questionnaire consisted of 71 questions. It was a full-scale study which allowed to obtain answers from all vocational

1 Act of 19 August 2011 on changes of the act on the educational system, introduced on 1 September 2012. Journal of Laws of 2011, no. 205, pos. 1206.

2 Rather low response rate encourages caution in generalisation of sample results. 
schools providing education in the school year 2015/2016, namely 16 technical high schools, 9 basic vocational schools and 2 colleges of further education ${ }^{3}$. The possibility of comparing opinions from both sides of cooperation is an additional advantage of the presented research.

Moreover, the following sources were used in order to realise the research goal: reports from focus group interviews organised for the purpose of diagnosing vocational education in the Lubelskie Voivodeship, general reports on vocational education, opinions of vocational education stakeholders who belong to Lublin Vocational Education Taskforce, Polish and foreign literature, and statistical data obtained from Central Statistical Office (CSO) and Eurostat.

\section{Cooperation of vocational schools with business in the City of Lublin - research results}

\section{A. Employers' perspective}

Table 1 presents the structure of entities participating in the survey. Comparing the structure of respondents to the structure of business entities in the City of Lublin, it can be observed that there is a relatively high proportion of large and medium entities. Such situation confirms positive correlation between the size of a company and readiness to cooperate with vocational schools, a relation which has already been documented in literature (e.g. Canning et al., 2007). The relatively bigger representation of industry and construction companies also remains consistent with empirical findings indicating a higher tendency of enterprises in this sector to cooperate with schools (e.g. IBRKK, 2010, p. 58). Employers usually seek cooperation in the following areas of education:

\begin{tabular}{lcccc}
\hline \multirow{2}{*}{ Specification } & \multicolumn{3}{c}{ Surveyed group } & Lublin (2015) \\
\cline { 2 - 5 } & number & Share (\%) & share (\%) \\
\hline Micro & \multicolumn{2}{c}{ Size } & 96.1 \\
\hline Small & 40 & & 42.1 & 3.0 \\
\hline Medium & 23 & 24.2 & 0.8 \\
\hline Large & 21 & 22.1 & 0.1 \\
\hline & 11 & & 11.6 & 16.4 \\
\hline Industry and construction & & Sector & 83.2 \\
\hline Services & 36 & & 37.9 & \\
\hline
\end{tabular}

Notes: Micro-enterprises employ up to 10 people, small - 10 to 49, medium - 50 to 249 , and large - 250 or more Source: Own research and data from CSO in Poland.

In one of the questions, the employers were asked to indicate and sort by priority up to five actions which in their opinion should be taken to strengthen vocational training and to adjust it to the requirements of labor market. Figure 1 presents the

\footnotetext{
3 Survey at schools was carried out jointly by the City Council of Lublin and the entity responsible for the document entitled Diagnosis and development plan for vocational education in the Lubelskie Voivodeship until the year 2025, commissioned by Konwent Powiatów Województwa Lubelskiego.
}

\author{
Cooperation \\ Between \\ Vocational \\ Schools \\ and Business \\ in Poland: \\ Schools'
}

vs. Employers'

Perspective
Table 1.

The structure of researched entities according to the size and type of business against the general background of business entities in Lublin 


\section{IJSR}

6

\section{Figure 1.}

Important actions to be taken in order to strengthen vocational education and to adjust it to the requirements of labor market (expressed in \%)

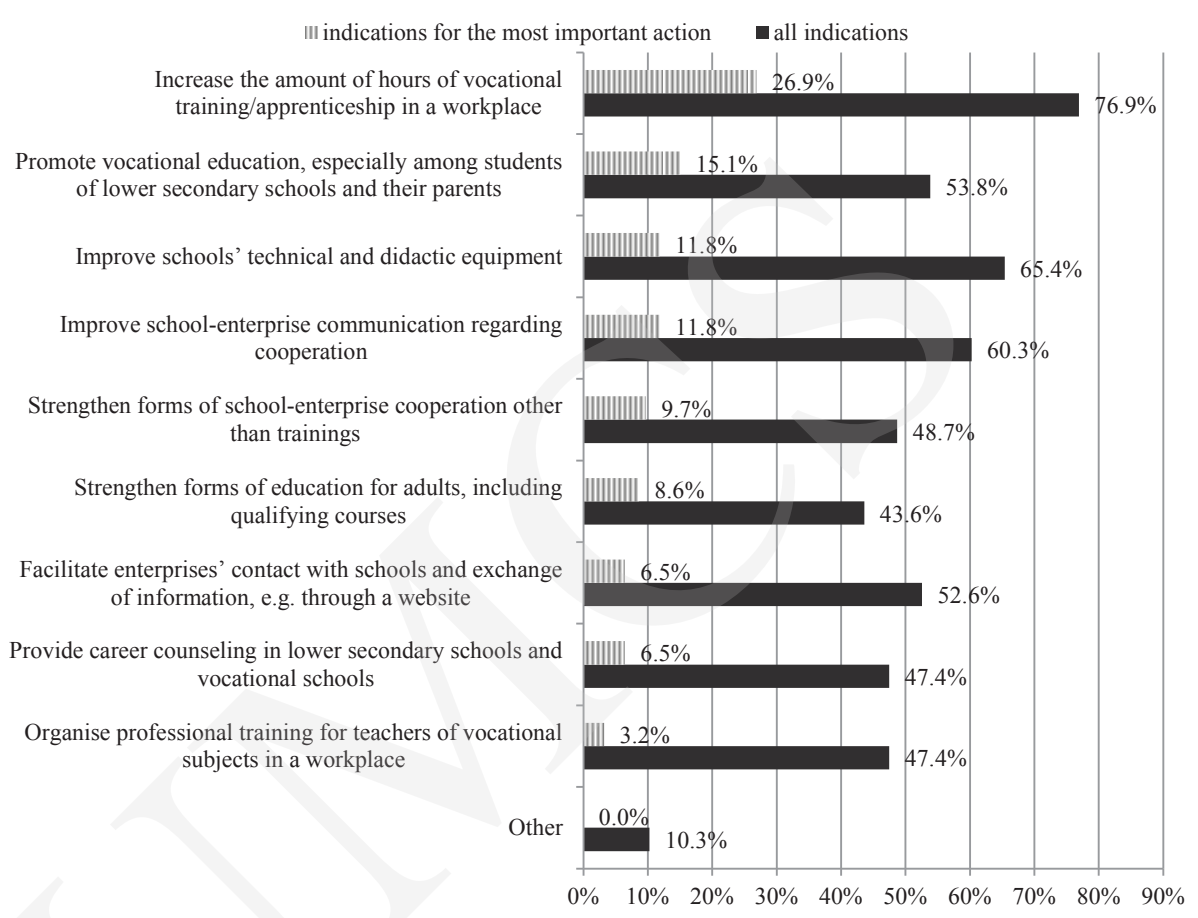

Note: The sum of all indications does not add up to $100 \%$, because the respondents could select up to 5 options. Source: Own research.

total number of indications and the percentage of indications of actions considered the most significant.

Most respondents indicated the need to increase the amount of hours of vocational training/apprenticeship, and most frequently considered this activity as the most important. Interpreting such results, one can make several conclusions. Firstly, practical vocational training is, according to the employers, the basic and most valuable instrument allowing for the adaptation of education to the needs of labor market. Secondly, employers have revealed the need to increase the number of hours of practical vocational training. It should be noted that, within the reform of vocational education implemented since 2012, the duration of vocational education has been significantly increased ${ }^{4}$. Due to the fact that the surveyed employers cooperate with schools, their answers might reflect an actual need to further extend the practical training beyond the current established size. Perhaps, practical training in too short blocks is also a problem. In Lublin schools, the usual length of a single training at one workplace is 160 hours, rarely

4 According to the Regulation of the Minister of National Education of 7 February 2012 on Framework Curricula in Public Schools (Journal of Laws 2012 item 204), theoretical vocational training in the whole cycle of education should take up a minimum of 735 hours in technical high schools and 630 hours in basic vocational schools, and practical vocational training should last 735 and 970 hours, respectively. Additionally, the so-called "hours at the headmaster's disposal" allow extending the duration of practical classes to the limit determined by the weekly amount of compulsory classes. 
320 hours. By comparison, in one of Lublin schools which offers dual education system to the students of construction as well as electric and electronic professions, students employed by companies as young workers have 840 hours of practical training per year.

The remaining responses are distributed more evenly among other forms of activity, both in terms of the total number of indications and the assigned rank. It can be argued that unimportant activities were not indicated or proposed. Respondents paid great attention to the need to improve schools' equipment and to promote vocational education in the society. Good communication with schools was also a crucial point. It is worth pointing out that the answers of medium and large enterprises were not significantly different from those of micro and small businesses.

Respondents were also asked to indicate up to 5 forms of cooperation between schools and enterprises that they considered the most valuable. Their preferences have been presented in Figure 2. According to the surveyed employers from Lublin, organisation of trainings and apprenticeships is the most valuable form of cooperation with vocational schools. Over $90 \%$ of representatives of the surveyed enterprises chose this form of cooperation. Vocational training and apprenticeships were by far the most frequently indicated option both in industry and construction, and in services, regardless of the size of the enterprise and the area of education covered by school-enterprise cooperation. While the dominant role of practical vocational training is not surprising, it is worth mentioning

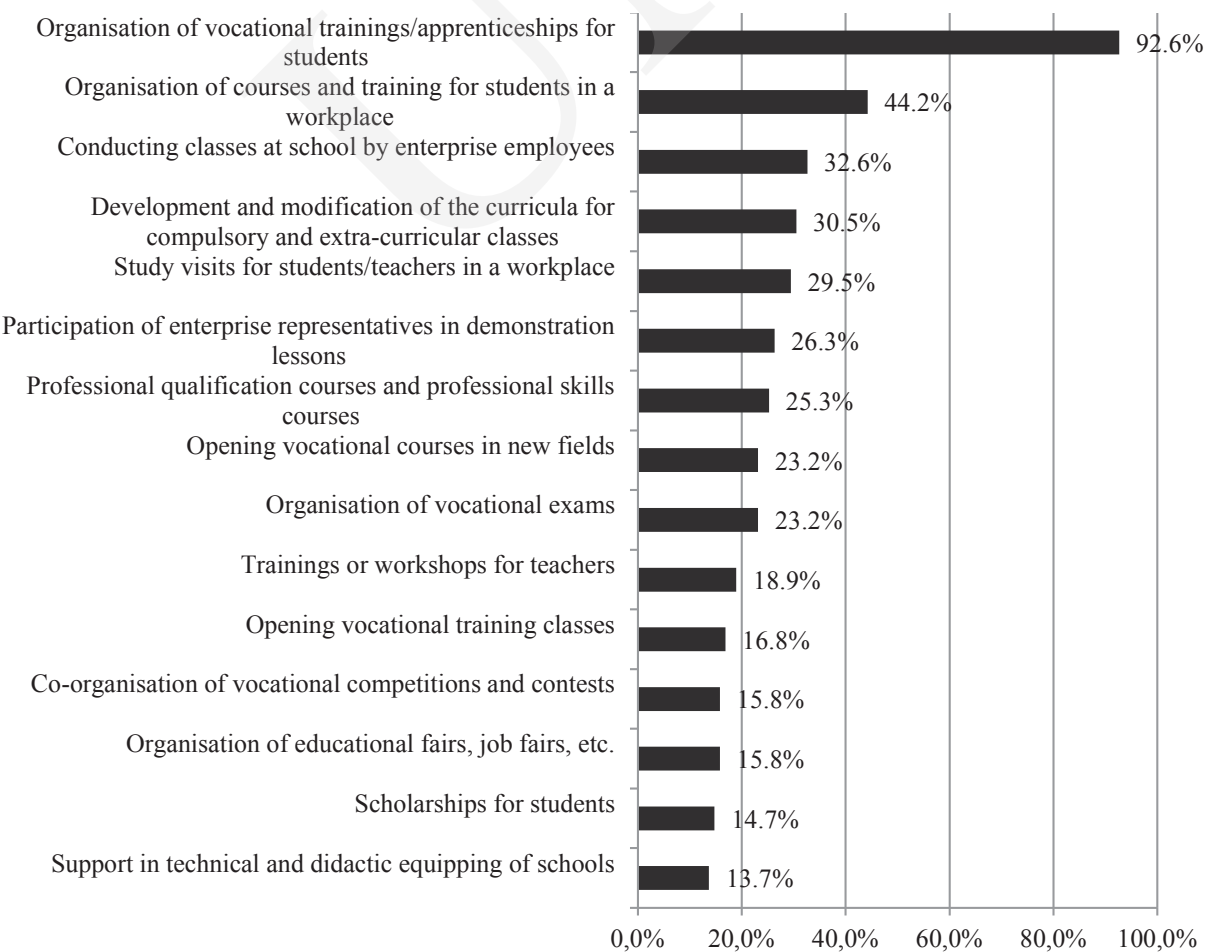

Note: The sum of all indications does not add up to $100 \%$, because the respondents could select up to 5 options. Source: Own research.

\section{Cooperation Between Vocational Schools and Business in Poland: Schools'}

vs. Employers' Perspective

Figure 2.

The most valuable forms of cooperation with vocational schools according to the employers (in \%) 
IJSR

6 employers' preferences regarding other forms of cooperation. The second most popular option were courses and workshops for students, and the third - conducting classes at school by enterprise employees. It is worth noting that the participation of enterprise representatives in demonstration lessons was also popular. Therefore, the employers value different forms of practitioners' participation in school education.

Basing on the survey results, it can be concluded that, according to the surveyed employers, irrelevant curricula are no longer the main problem of vocational education. Cooperation in terms of development and modification of the school programs was ranked in the fourth place and opening new vocational courses in eighth. Such indication by employers cooperating with schools can be interpreted as a proof of generally successful curricula modernisation within the reform of vocational education implemented since 2012.

What is striking is the low percentage of indications for cooperation in organisation of external vocational exams which, according to the assumptions of the reform of vocational education, should play the key role in the verification of the quality of education and in education's adjustment to the needs of labor market ${ }^{5}$. In focus group interviews organised in order to diagnose vocational education in the Lubelskie Voivodeship, the employers usually pointed out the considerable progress in drawing vocational exams closer to the real working environment after the reform of vocational education (Konwent Powiatów Województwa Lubelskiego 2016). In contrast, other research suggests that employers, especially those who train students in the mechanical and mining field, assessed very poorly the significance of these exams in confirming graduate's professional competences (Kicia, Zajkowski, 2012). It seems that there are two possible explanations to such low percentage of indications for this form of cooperation. Firstly, most employers may not be aware of that they can actively participate in vocational exams. Secondly, little interest in participation in the exams might stem from the negative evaluation of cooperation with schools in this field. Reasons for negative perception of vocational exams might be different. For instance, the entrepreneurs can be discouraged by procedural requirements (including obtaining powers of regional examination boards), extensive duration of the exams connected with employees' absence from work, or relatively small financial benefits for enterprise employees.

Another puzzling result is the last position of employers' support in equipping schools with technical and didactic materials, which often is a key problem for school headmasters. In the previously analysed question the employers indicated the need to improve schools' technical and didactic equipment. Low number of indications in this question might stem from the fact that only few employers are prepared to support schools in this respect, while the vast majority regards this issue as the sole responsibility of headmasters and local governments. It is worth noting that the size of a company does not differentiate the provided answers. This form of cooperation was, however, chosen more frequently by employers from those branches of industry in which adjustment of school equipment to the market realities is much more expensive than it is in the case of many kinds of services.

Only few employers indicated improvement of teachers' qualifications, especially for teaching vocational subjects. Such results can be explained in various ways. On the one hand, it might be a sign of a positive evaluation of teachers' knowledge. Still, other research

$5 \quad$ See: Cedefop (2011, p. 42) for more details. 
on the subject often mentions negative opinions of enterprise representatives in this field (e.g. IBRKK 2010, p. 86; Konwent Powiatów Województwa Lubelskiego 2016). On the other hand, it is more probable that low percentage of indications results from low conviction as to the effectiveness of different forms of improving teachers' qualifications, or from reluctance to engage in such initiatives. The latter might be due to the fact that teachers' training is a much more demanding task than organizing practical training for students.

Employers' willingness to cooperate with vocational schools should be proportional to the difficulties they experience in finding workers. Therefore, the enterprise questionnaire included questions concerning experience in the recruitment process. It turned out that the vast majority of respondents employed new workers in the last three years. $78.9 \%$ of the surveyed enterprises, including almost all large and medium companies, searched for workers with vocational education within the period of three years prior to the survey. In the majority of cases vocational education was one of the criteria taken into account during the recruitment (see Figure 3).

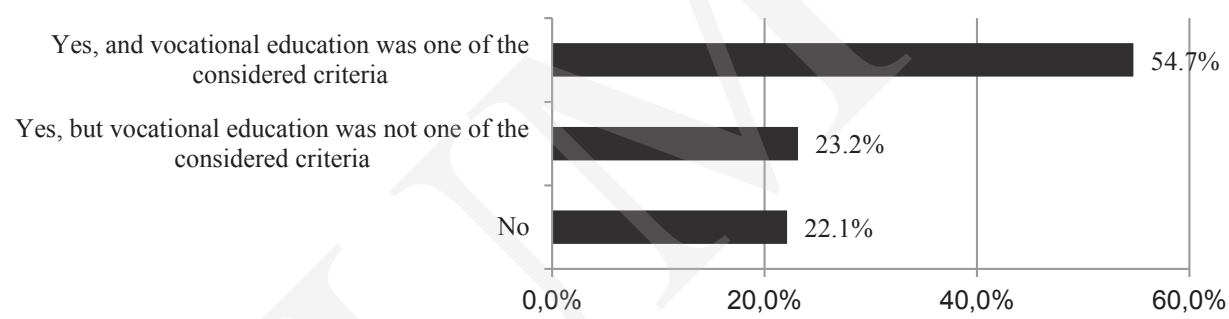

Source: Own research.

At the same time, $61.1 \%$ of employers in this period employed workers who earlier served vocational training or apprenticeship at their enterprise. What remains puzzling is the fact that, despite the possibility to recruit trainees, many employers seeking workers with vocational education signaled problems with recruitment. Only under $30 \%$ of employers filled all vacancies with candidates having required professional qualifications, which can be interpreted as no difficulties in recruitment (see Figure 3). $37 \%$ of respondents reported problems during the recruitment process. Although they filled all positions, some of the new employees did not have the required qualifications. As many as one third of the respondents encountered serious problems with recruitment, so that they did not manage to fill all the vacant positions (see Figure 4).

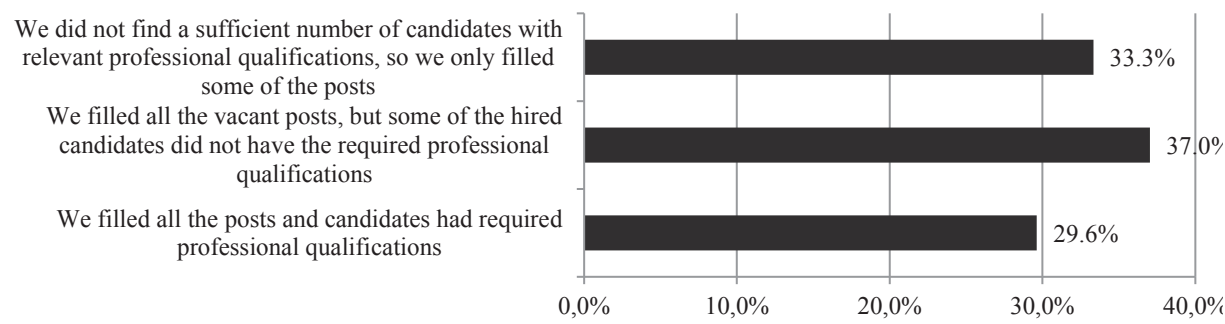

Source: Own research.

\section{Cooperation Between Vocational Schools and Business in Poland: Schools' vs. Employers' Perspective}

Figure 3.

Distribution of answers to the question "Did you want to employ workers with vocational education in the last three years?"
Fiĝure 4.

The results of recruitment in companies searching for workers with vocational education 


\section{IJSR}

6

Figure 5.

Competences of graduates from vocational schools in Lublin - distribution of employers' assessment
It seems that there are two possible explanations of the situation, beside the apparent arguments regarding search frictions and mismatch. Either the number of trained students were insufficient in relation to the reported demand for labor, or the differences in students' competences and employers' requirements were so vast that the employers resigned from hiring workers signaling very low productivity. In the light of the research results, the second explanation seems less likely. The survey allowed the employers to choose those competences from the list of 20 to which they pay particular attention, and then to assess, on a five-grade scale, the level of those competences in graduates from vocational schools. Respondents' indications were dominated by "average" (3) and "rather high" (4) notes (see Figure 5). These notes also dominated the assessment of three competences closely related to vocational education: machine and equipment operation, basic professional skills and specialised professional skills.

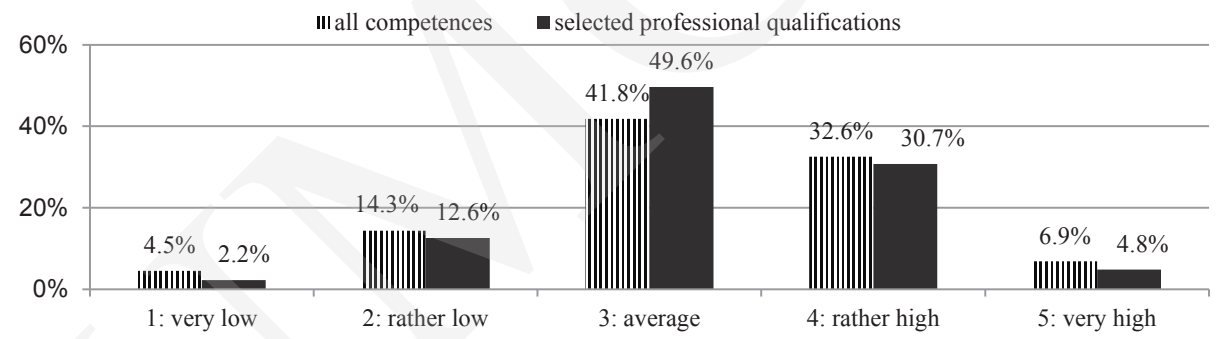

Note: Employers could choose the following competences: machine and equipment operation, basic professional skills, specialised professional skills, computer skills, communication in a foreign language, flexibility/ ability to adapt to change, creativity, responsibility, self-control in conflict and stressful situations, focus on the results and objectives, basic mathematical skills and basic competences in science and technology, sense of initiative and enterprising, independence, diligence and accuracy, analytical skills, ability to communicate with clients and coworkers, ability to organise and plan own work, ability to work in a team, ability to solve problems and conflicts, ability to learn. First three competences were categorised as 'selected professional qualifications'.

Source: Own research.

\section{B. Schools' perspective}

Recruitment of students is among the most pressing problems indicated by the representatives of vocational schools in the City of Lublin. Only 8 out of 27 surveyed schools had no problems with recruiting students in the school year 2015/2016 and formed as many classes as they had planned. 11 schools in Lublin, mainly basic vocational schools, experienced serious problems with finding students. Within the last two years, unsuccessful recruitment to basic vocational schools and technical high schools concerned the following professions: car tinsmith, roofer, electrician, mechanicfitter of machine and equipment, locksmith, ham and sausage maker, electrical mechanic, hairdresser, photographer, mechanic for industrial automation and precision devices, restoration of architectural elements technician, and lifting equipment technician. When asked about the reasons for such situation, the headmasters indicated the declining youth population and dwindling popularity of vocational education among young people. It is worth noting that some of the professions listed above, especially mechanic-fitter of machine and equipment, locksmith and mechanic for industrial automation and precision 
devices, are regarded as extremely scarce professions, i.e. in deficit on the local labor market (Barometr zawodów..., 2016; Maleszyk, 2017). This shows that there is a need to increase the awareness of young people and their parents on the unfulfilled labour demand for vocational schools' graduates.

While analysing the perception of vocational education by school headmasters it is worth referring to the question in which the respondents were asked to indicate school's strengths and weaknesses. Most schools provide education in more than one profession, therefore, the respondents were asked to indicate strengths and weaknesses of education in each profession. As a result, 74 responses were collected. The structure of indications is represented in Figure 6. Interpretation of the obtained results should take into account the fact that the headmasters had a significantly higher tendency to indicate their schools' strengths - the number of indications was three times higher than that of weaknesses.

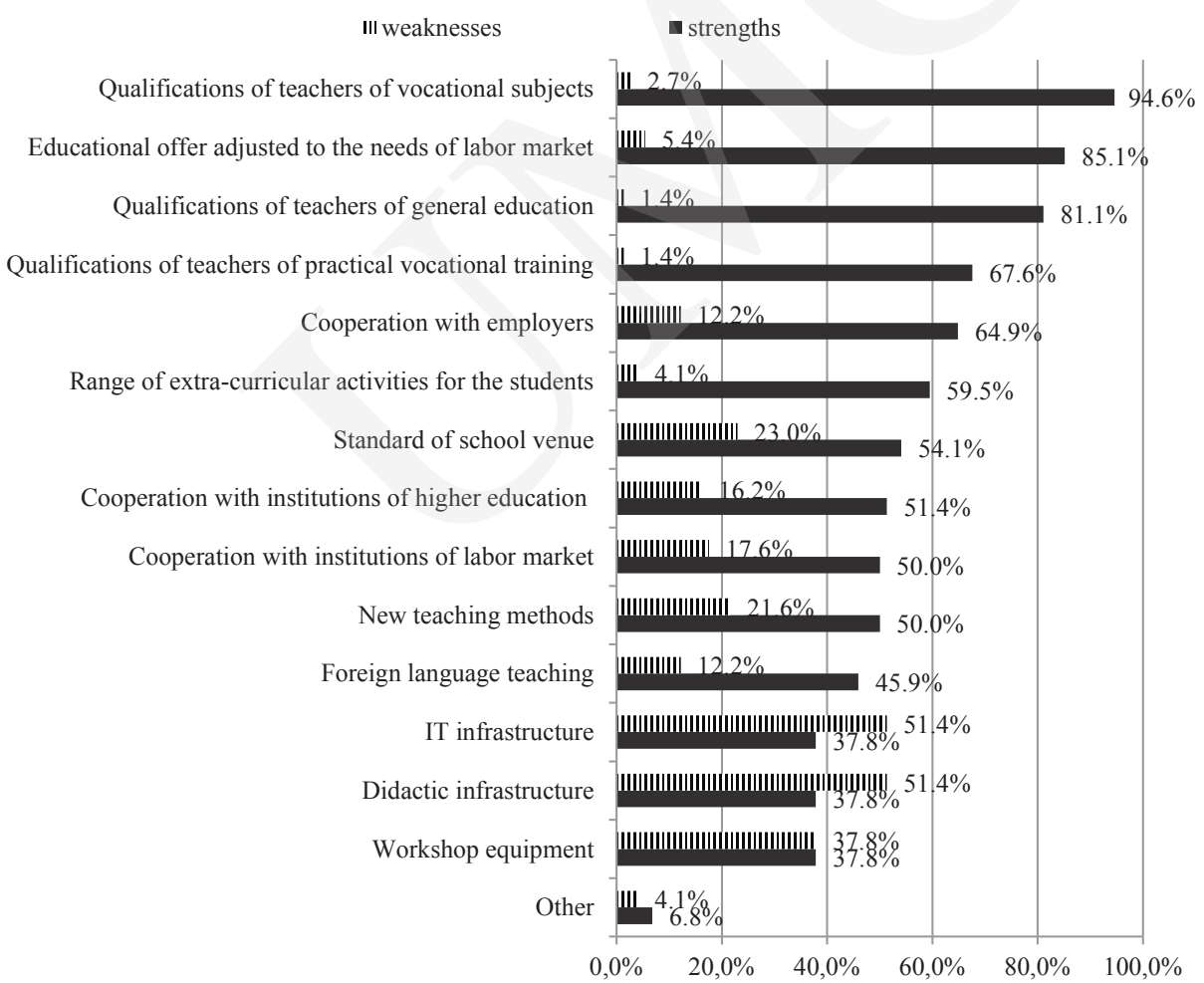

Source: Own research based on data from the Lublin City Office.

The main advantages of vocational schools in Lublin indicated by the headmasters were: the qualifications of teachers of vocational subjects (providing theoretical vocational education), educational offer adjusted to the needs of labor market and the qualifications of teachers of general education. Interestingly, the percentage of indications for the qualifications of teachers of practical training (providing practical vocational education) is visibly lower. This fact is particularly significant as focus group interviews or the

\section{Cooperation Between Vocational Schools and Business in Poland: Schools'} vs. Employers' Perspective

Figure 6. Strengths and weaknesses of vocational schools in Lublin according to their headmasters 
IJSR

6

meetings of Lublin Vocational Education Taskforce signaled on numerous occasions the problem with recruiting teachers of practical vocational subjects and with finding replacement for the retiring staff, especially for education in the fields of construction and mechanical and mining. Similar problem is constituted by high costs of training for teachers of vocational subjects for industry and construction as well as for the profession of IT technician. Completing these trainings is often a mandatory condition for school to obtain permission to issue certificates confirming particular skills.

According to the headmasters, the main problems of vocational schools comprise of deficiencies in educational infrastructure, including deficiencies in workshop equipment and outdated IT infrastructure. It is worth adding that the purchase of workshop equipment was the most frequent answer to the question about the types of projects for the following programming period of the EU structural policy for the years 2014-2020.

Cooperation of schools with employers was indicated as an asset in education with reference to almost $2 / 3$ of professions, despite a relatively large percentage of indications for this category as a schools' weakness. Compared to other indications, such result might mean that schools already have a number of partners in the business environment, a number which is sufficient to provide compulsory practical vocational training. Consequently, organisation of compulsory vocational training does not pose a major problem for schools. What still remains the priority are the school resources: teaching staff and infrastructure.

\section{Barriers to cooperation of vocational schools with employers - discussion}

The comparison of the two surveys' results shows the discrepancy in the interests of employers and schools. The employers care for and insist on the increase in the number of hours of students' practical vocational training in a workplace. They also indicate the need to improve the equipment of school workshops, but are not willing to share related costs. The employers assess graduates' competences as average or rather good, rarely expressing willingness to participate in vocational exams and trainings for teachers. Thus in general, they remain unwilling to undertake more costly and more demanding forms of cooperation with schools, despite the relatively high intensity of recruitment problems. Meanwhile, schools indicate, above all, the need to improve their own resources, especially workshop equipment. They have contact with employers who provide practical vocational training, and frequently consider cooperation with business environment as school's strength. Many schools, however, are confronted with the problem of recruiting sufficient number of students. Hence, the indicated asymmetry of schools' and enterprises' objectives must be regarded as an important barrier to the development of cooperation between vocational schools and business. In this situation it can be recommended that EU structural funds should be allocated primarily to these forms of cooperation between vocational schools and enterprises which are not equally attractive to both parties. "Package" structure of projects is also worth considering. Such structure could assume that in order to ensure cooperation favourable for the employers, they would have to engage in vocational exams or trainings for teachers. Still, the overall balance of costs and benefits from the cooperation would be favourable for enterprises. 
Against the background of the obtained results it is worth considering why enterprises in Lublin manifest limited willingness to engage in areas of cooperation significant for vocational education, despite experiencing recruitment problems ${ }^{6}$. Reference to the conditions determining the success of German dual education system might be useful in attempting to address this issue.

First of all, the enterprise sector in the City of Lublin, and in Poland, is very fragmented. Micro-enterprises in Poland constitute 95.2\% of all enterprises, in Lublin $96 \%$, and in Germany $-83.6 \%$. In Lublin and in Poland, the share of medium and large enterprises, which are potentially the most valuable partners for vocational schools, is more or less 2.5 times smaller than in Germany (see Figure 7).

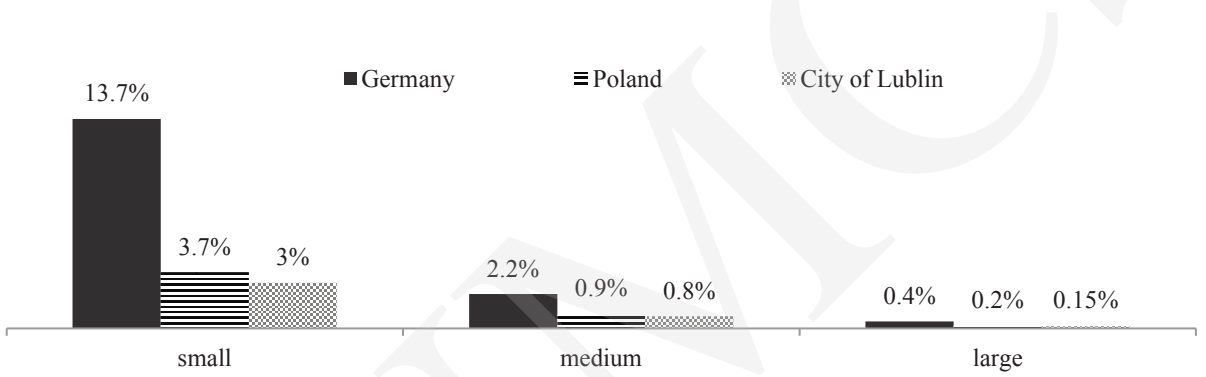

Source: Own research based on data from Eurostat (Poland and Germany) and CSO Local Data Bank (Lublin). Data for the year 2014.

The size of the company affects the structure of the costs and benefits from the cooperation with vocational schools. The possibility to recruit qualified workers is the most valuable benefit for the companies. In particular, the cooperation can help in adjusting education offered by schools to the needs of specific enterprise, gaining insight into students' skills and selecting the best candidates. Thanks to the network of contacts, the employers reduce the cost of recruitment, avoid wrong decisions in the selection of candidates, and reduce staff turnover. They also benefit from shortening the integration period for a new employee or from seasonal employment of young people during the holiday period (see e.g. Hoeckel, 2008, NCFSVCE, 2011). Such benefits are, however, primarily enjoyed by medium and large enterprises, while smaller companies rarely recruit new employees. Instead of engaging in cooperation with schools, they prefer to obtain workers in an easier way, e.g. through acquaintances' recommendations or by recruiting them from the open market (NBP, 2016). Fila et al. (2014) argue that costs associated with taking on students for vocational training by micro and small companies (such as consumption of materials, tool damage, time devoted by staff to supervise students) are a bigger burden for these enterprises than for larger entities. It is worth noting that the most significant benefits from enterprises' cooperation with schools are revealed in the longer term, while the structure of costs is dominated by short-term ones. Meanwhile, market strategy of small companies is more frequently based on adjustment

6 Discussion of barriers to cooperation between schools and employers connected with education in vocational schools can be found, for instance, in post-inspection report of the Supreme Audit Office (NIK 2016).

\author{
Cooperation \\ Between \\ Vocational \\ Schools \\ and Business \\ in Poland: \\ Schools' \\ vs. Employers' \\ Perspective
}

Figiure 7.

Percentage of small, medium and large enterprises in the City of Lublin, Poland and

Germany 
IJSR

6

to the current market situation, rather than to achieving long-term development goals.

Poorly developed cooperative bonds among enterprises are another barrier to the cooperation between employers and vocational schools in the City of Lublin and in Poland. Meanwhile, employers in Germany are well organised into associations and unions (the so-called corporatist model). For instance, for many years wage negotiations have been conducted via collective bargaining at industry level, i.e. between representations of employers in a given industry and the largest trade unions. The presence of strong employers' associations facilitates cooperation with schools and the adjustment of education to the needs of labor market. In Poland, Lublin included, collective bargaining is decentralised, and wages are set at firm's level. Consequently, cooperative bonds between employers (e.g. trade associations or industrial clusters) are of little importance. In such conditions, the agreement of several employers in one branch of industry, e.g. to jointly order a new field of education, to delegate an employee to participate in vocational exams, or to establish a vocational education centre, is much more difficult.

Thirdly, recruitment problems of Polish employers are a relatively new phenomenon. For many years in Poland, the unemployment rate remained on a two-digit level, and unemployment rate in Lublin was one of the highest among the provincial cities in the country. Entrepreneurs in Lublin felt no incentive to cooperate with schools because they could easily recruit a worker on the open labor market ${ }^{7}$. A clear intensification of recruitment problems occurred only after 2014; however, individual sectors and professions are not equally confronted with these problems (NBP, 2016). In Germany, labor shortage (especially in industry) has persisted for many years (Rinne, Zimmermann, 2011); therefore, the cooperation with schools, which allows for finding the needed workers, is among the enterprises' highest priorities.

Finally, cooperation of enterprises with vocational schools in Germany is rooted in the German system of values. As noted by Dziedziczak-Foltyn and Brzeziński (2013, p. 79) in one of the most comprehensive reports on the perspective of dual education implementation in Poland, German 'voluntary responsibility' of business for vocational education is probably unique in the world. This commitment translates into a willingness to share the cost of educating the youth. In Poland and in Lublin, employers' willingness to bear costs of dual education is significantly lower.

\section{Conclusions}

The comparison of the survey results confirms that incompatible interests of vocational schools and enterprises are one of the barriers to cooperation between the two. Employers are set on increasing the number of hours of students' practical vocational training in the workplace. They also indicate the need to improve workshop equipment at schools, but are reluctant to cover the related costs. Rarely do they express willingness to participate in vocational exams and teachers' training. In general, employers are reluctant to undertake more costly and more demanding forms of cooperation with schools, despite growing recruitment problems. Meanwhile, schools primarily indicate the need to

\footnotetext{
See: WUP (2015) for more details.
} 
improve their own infrastructure, especially workshop equipment. They already have contacts with employers who provide vocational training, often considering the present state of cooperation with business as satisfactory. Instead, many schools face the problem of recruiting a sufficient number of students.

In the discussion on the determinants of cooperation between vocational schools and enterprises it has also been noted that the employers' limited willingness to engage in the areas of cooperation important for the vocational education stems not only from vocational education system itself, but also from structural features of the enterprise sector in Poland: its fragmentation, poorly developed cooperative bonds between enterprises, and the fact that cooperation with schools is not embedded in the system of values. The limited willingness to cover the costs of dual education is also due to the small scale of recruitment problems during most of the last two decades.

\section{References}

Barometr zawodów 2016. Miasto Lublin [Occupational Barometer. The City of Lublin]. Retrieved March 11, 2017 from: https://barometrzawodow.pl/lubelskie/plakaty

Canning, M., Godfrey, M., Holzer-Zalezewska, D. (2007). Vocational Education in the New EU Member States: Enhancing Labor Market Outcomes and Fiscal Efficiency, World Bank Working Paper, 116: World Bank.

Cedefop (European Centre for the Development of Vocational Training) (2011). Poland. VET in Europe - Country Report 2011, Luxembourg.

CSO Local Data Bank, https://bdl.stat.gov.pl/BDL/start [access: 11.03.2017].

Deissinger, T., Hellwig, S. (2005). Apprenticeships in Germany: Modernising the Dual System, Education + Training, vol. 47, no. 4/5, pp. 312-324, DOI: 10.1108/00400910510601896.

Dziedziczak-Foltyn, A., Brzeziński, K. (2013). Kształcenie zawodowe i kształcenie dualne $w$ Polsce $i$ województwie tódzkim. Stan obecny i perspektywy rozwoju [Vocational education and dual education in Poland and in the province of Łódź. Current situation and prospects of development], HRP Group - ASM, Łódź.

Eurostat Database, http://ec.europa.eu/eurostat [access: 11.03.2017].

Fila, J., Rybińska, A., Trzciński, R. (2014). Wspótpraca szkół zawodowych z przedsiębiorcami na przykładzie Działania 9.2 PO KL [Cooperation of vocational schools with entrepreneurs on the example of the 9.2 PO KL activity], Instytut Badań Edukacyjnych, Warsaw.

Hoeckel, K. (2008). Costs and Benefits in Vocational Education and Training, OECD, Paris.

IBRKK (Institute for Market, Consumption and Business Cycles Research) (2010). Absolwenci szkolnictwa zawodowego w Lublinie i Chetmie wobec sytuacji na rynku pracy [Graduates from vocational schools in Lublin and Chełm in the view of the situation on labor market], Warsaw.

Jeruszka, U., (ed.), (2012). Unowocześnienie metod i form ksztatcenia zawodowego w Polsce. Diagnoza i oczekiwane kierunki zmian [Modernising methods and vocational training form in Poland], IPiSS, Warsaw.

Kabaj, M. (2010). System kształcenia zawodowego i kierunki jego doskonalenia $w$ warunkach integracji $i$ wzrostu konkurencyjności: diagnoza i element program szerszego wdrożenia dualnego system ksztatcenia $w$ Polsce [Vocation education system and the course of its improvement in the conditions of integration and increase in competitiveness: diagnosis and program elements of wider implementation of dual system of education in Poland], Związek Rzemiosła Polskiego, Warsaw.

Kicia, M., Zajkowski, R. (2012). Uwarunkowania wspótpracy zasadniczych szkół zawodowych i pracodawców $w$ województwie lubelskim. Raport z badania kluczowego [Conditions of

\author{
Cooperation \\ Between \\ Vocational \\ Schools \\ and Business \\ in Poland: \\ Schools' \\ vs. Employers' \\ Perspective
}


IJSR

6 cooperation between basic vocational schools and employers in the Lubelskie Voivodeship. Pivotal study report], Fundacja PAN, Lublin.

Konwent Powiatów Województwa Lubelskiego [Convent of Districts of the Lubelskie Voivodeship] (2016). Diagnoza i plan rozwoju szkolnictwa zawodowego w województwie lubelskim do roku 2025 [Diagnosis and development plan for vocational education in the Lubelskie Voivodeship until the year 2025], Lublin.

Maleszyk, P. (2017). Trafność identyfikacji zawodów nadwyżkowych i deficytowych w Barometrze Zawodów [Identification accuracy of the occupational barometer for deficit and surplus occupations]. Rynek Pracy, no. 1(160), pp. 21-33.

NBP (National Bank of Poland) (2016), Badanie ankietowe rynku pracy. Raport 2016 [Labour Market Survey. Report 2016], Warsaw.

NCFSVCE (National Centre For Supporting Vocational And Continuing Education) (2011), Badanie funkcjonowania system ksztatcenia zawodowego w Polsce. Raport końcowy [The study on the system of vocational education in Poland. Final report], Warsaw.

NIK (Supreme Audit Office) (2016), System szkolnictwa zawodowego [System of vocational education], Warsaw, https://www.nik.gov.pl/plik/id,11897,vp,14269.pdf [access: 11.03.2017].

Regulation of the Minister of National Education of 7 February 2012 on Framework Curricula in Public Schools, Journal of Laws of 2012, item 204.

Rinne, U., Zimmermann, K. (2011). Another Economic Miracle? The German Labor Market and the Great Recession. IZA Journal of Labor Policy, vol. 1, no. 3, DOI: 10.1186/2193-9004-1-3.

Thelen, K. (2007). Contemporary Challenges to the German Vocational Training System, Regulation \& Governance, no. 1, pp. 247-260, DOI: 10.1111/j.1748-5991.2007.00013.x.

WUP(Voivodeship Labour Office in Lublin) (2015). Potrzeby i oczekiwania pracodawców. Raport z badań ilościowych pracodawców województwa lubelskiego zatrudniajacych co najmniej 10 pracowników [Employers' Needs and Expectations. Report on quantitative research on employers employing 10 employees or more in the Lubelskie Voivodeship], Lublin. 